\title{
Grafitecidade como Plataforma Produtora de Imagens na Cartografia Urbana
}

\author{
Graffiticity as a platform for producing images in urban cartography
}

José Geraldo Oliveira - Universidade Paulista e Faculdade Cásper Líbero | São Paulo | SP | Brasil | E-mail: zegera@hotmail.com | https://orcid.org/0000-0003-3067-8413

\begin{abstract}
Resumo: Grafitecidade é um espaço de ação em que agentes transgressores se apropriam esteticamente da cidade e a transformam em uma plataforma de imagens. A proposta deste ensaio é uma reflexão sobre a paisagem urbana como uma narrativa através da ação dos grafiteiros, agentes contemporâneos de comunicação e de apropriação do espaço urbano. Um território de metáforas em movimento que em seu caráter efêmero reúne pontos de tensões dialéticas. Uma paisagem ritmada pela interação do observador em movimento que produz olhares nos interstícios urbanos, já que o corpo do observador também está ali e deseja interagir. O caminhante pode perceber fragmentos das várias cidades contidas na cidade, em que os grafiteiros impõem uma comunicação que transita entre a agressividade e a passividade do observador, ao mesmo tempo em que busca criar um território de diálogo hibrido onde confluem as tensões, o pertencimento, a identidade.
\end{abstract}

Palavras-chave: Grafitecidade. Visão travelar. Cidade. Espaço urbano. Montagem subjetiva.

Abstract: Graffiticity is a space of action in which graffiti artists esthetically take the city and transform it into an image-producing platform. The proposal of this essay is a reflection on the urban landscape as a narrative through the action of graffiti artists, contemporary agents of communication and appropriation of urban space. This space is a territory of moving metaphors that, in its ephemeral nature, gathers points of dialectical tensions; a landscape rhymed by the interaction of the moving observer that produces glances in the urban interstices, since the observer's body is also there wanting to interact. The bystander can perceive fragments of various cities contained in the city, where graffiti artists impose a communication that goes from the aggressiveness to the passivity of the observer and seek to create a territory of hybrid dialogues where tensions, belonging and identity converge.

Keywords: Graffiticity. Travelling vision. City. Urban space. Subjective montage.

- Recebido em: 28 out. 2019 • Aprovado em: 02 dez. 2019 e-ISSN: 2177-5788

DOI: https://doi.org/10.22484/2177-5788.2019v45n2p331-357

Copyright @ 2019. Conteúdo de acesso aberto, distribuído sob os termos da Licença Internacional da CreativeCommons - CC BY-NC-SA - Atribuição Não Comercial (https://br.creativecommons.org/licencas/) - Permite distribuição e reprodução, desde que atribuam os devido créditos à publicação, ao autor(es) e que licenciem as novas criações sob termos idênticos. 
A identidade do indivíduo exige um esforço constante de inclusão, uma história que lembra a de Gilgamesh que, para saber o que cada um é, são necessários pelo menos dois homens.

Alberto Manguel (2008)

\section{Introdução}

O objetivo deste ensaio é uma reflexão sobre a paisagem urbana como narrativa, especificamente a partir da ação dos artistas transgressores ${ }^{1} \mathrm{e} a$ sua "arte bastarda das ruas de má fama", segundo o fotógrafo húngarofrancês, Brassaï, que "tão menosprezada que mal é capaz de despertar nossa curiosidade, tão incerta que as inclemências do tempo podem apagála (BRASSAÏ, 2008, p. 36).

Para iniciar proponho uma pergunta como provocação: consegue lembrar uma imagem, qualquer que seja ela, vista hoje durante algum trajeto pela cidade? Se lembrar, consegue descrever esta imagem? A resposta para esta pergunta pode ser difícil e nos levar a uma série de reflexões.

Martine Joly (2012), em La imagen fija, aponta uma distinção fundamental entre a imagem fixa e a imagem em movimento: as primeiras podem "ser contempladas enquanto as outras [em movimento], necessariamente, desfilam. Temos tempo, conforme Joly (2012), de observar e inclusive contemplar as primeiras, mas só de recordar as segundas. A autora está tratando a imagem em movimento relacionadas ao cinema e a televisão, entre outras, no nosso caso, estamos incluindo uma outra capa à discussão: o movimento do observador durante um percurso pela cidade.

\footnotetext{
${ }^{1}$ Trato como artista transgressor quem produz qualquer tipo de inscrição no espaço urbano sem autorização e que estão à margem do vandalismo e da criminalidade. Entendo este ato como uma forma de transgressão em busca de voz nos espaços dominados pela publicidade institucionalizada. A legislação brasileira não difere entre grafite e pichação, e a sua punição está prevista no 0 art.65 da Lei no 9.605/98 (Lei de Crimes Ambientais).
}

REU, Sorocaba, SP, v. 45, n. 2, p. 331-357, dez. 2019. 
Nas cidades, sobretudo nas grandes cidades, o deslocamento é contínuo, apressado, e a percepção das imagens nos foge, muitas vezes lembramos de pequenos fragmentos, situações, contexto, mas quase sempre não conseguimos lembrar de uma imagem em si. Neste sentido, a percepção da imagem se dá por "montagem subjetiva". O que chamamos de montagem subjetiva é uma aproximação ao efeito Kulechov, desenvolvido pelo cineasta russo Lev Kulechov². Uma experimentação que irrompe espaços físicos-temporais. Este conceito explora a criatividade da operação da montagem, que tornou este processo - mecânico e criativo responsável por estabelecer uma nova linguagem.

\section{As Configurações da Identidade e Pertencimento}

É lugar comum dizer que a cidade é um espaço humano de cultura e de comunicação, entendendo a cultura como o cultivo das potencialidades humanas e a comunicação o "intercâmbio" dessas potencialidades. É possível dar um passo a mais e pensar em "configuração" destas potencialidades. Se somente falarmos de "intercâmbios", ficaremos apenas no nível informativo; se falamos de "configuração", abrimos para a potencialidade do feedback, e consequentemente, o poder da comunicação de possibilitar as potencialidades.

A cidade é um emblemático campo comunicacional e os artistas transgressores, ao apropriar-se da geografia urbana, elaboram uma guerrilha informacional na escala humana. Rossana Reguillo-Cruz, em Pensar la ciudad desde la comunicación, postula que:

Olhar a cidade a partir da comunicação implica, em primeiro lugar, trabalhar a relação entre cultura objetivada e cultura incorporada, quer dizer, a observação da presença de agências, instituições, discursos e práticas objetivadas nas representações dos atores urbanos (REGUILLO-CRUZ, 1995, p. 123).

2 Kuleshov intercalou frames da face "inexpressiva" do ator Ivan Mosjouskine com imagens de um prato de sopa, uma criança morta e uma mulher atraente.

REU, Sorocaba, SP, v. 45, n. 2, p. 331-357, dez. 2019. 
Ao reivindicar pertencimento e identidade, os transgressores provocam uma experiência visual que busca provocar um debate sobre as relações sociais e que coloca em xeque o próprio conceito de arte. ReguilloCruz (2000) nos lembra que a identidade não é uma essência, mas sim de um conceito relacional que supõe simultaneidade de um processo de identificação e um processo de diferenciação, o que implica necessariamente uma tarefa de construção. A identidade se constrói na interação com o outro, os iguais e os diferentes: a identidade instaura sua própria alteridade. Da mesma forma que sabemos que as identidades são históricas, conforme Reguillo-Cruz (2000), no pensamento atual abre-se um debate importante em torno das identidades efêmeras e cambiantes, que não seriam mais identidades, mas identificações.

A identidade é uma relação objetiva que se estabelece entre o portador e o meio social onde se desenvolve, uma plataforma a partir da qual se interage com os demais, uma peça delicada cujo funcionamento requer uma manutenção constante e do suporte material que lhe dê sentido: a identidade necessita exteriorizar-se, objetivar-se de algum modo (REGUILLO-CRUZ, 1991, p. 32).

A arte urbana transgressora por seu caráter dialético e sua inserção na paisagem resgata algo que não se retrata, algo produzido entre o olhar e o mundo, e que não é uma simples representação, mas um ato político insertado no contexto da comunicação visual urbana. Como objetos de cultura, essas inscrições urbanas apresentam simultaneamente uma realidade material e uma realidade simbólica. Neste diálogo de descontinuidades podemos estabelecer o lugar das imagens na grafitecidade como uma obra, como uma montagem de tempos, pois,

Uma imagem, ao contrário, é aquilo em que o Pretérito encontra o
Agora em um relâmpago para formar uma constelação. Em outros
termos, a imagem é a dialética em suspensão. Porque a relação do
presente com o passado é puramente temporal e contínua, a relação
do Pretérito com o Agora presente é dialética: não é algo que se
desenvolve, mas uma imagem fragmentada. Só as imagens
dialéticas são imagens autênticas (BENJAMIN apud DIDI-
HUBERMAN, 1998, p. 114).

Grafitecidade é a junção do termo grafite e cidade. Significa ao mesmo tempo uma plataforma produtora de imagem, onde o campo visual é 


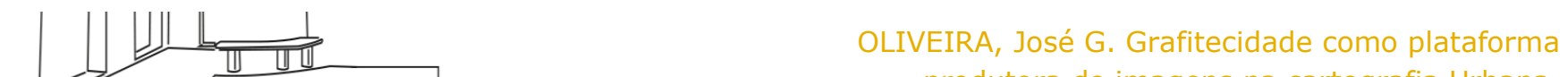

convertido e uma superfície de inscrições e espaço de aglutinação de perspectivas e linguagens, pelo viés da fenomenologia do olhar, conforme sugerido por Oliveira (2014).

A cidade não é só a construção física, mas uma rede de relações em que o discurso visual é expansivo e está incrustado em uma constelação de significados que contém distintas gramáticas visuais fabricadas coletivamente.

\section{Grafitecidade, uma Plataforma de Imagens Transgressoras}

A Grafitecidade é um espaço de ação, coletiva ou não, que se apropria esteticamente dos "não-lugares", segundo Foucault (2010), e os transforma numa plataforma produtora de imagens e de suas múltiplas identidades, seja para questionar a realidade social ou para interferir esteticamente, transformando zonas de trânsitos em espaços "vividos", "concebidos", utilizando a nomenclatura de Lefebvre (2013). São espaços que ficam reduzidas ao silêncio, apesar de ter muito a "falar", como o ventríloquo que dá voz a uma figura que permanece muda atrás dela.

$\mathrm{Na}$ grafitecidade, o espaço se converte em uma superfície de inscrições narrativas e um espaço de aglutinação de perspectivas e linguagens visuais e textuais (Figura 1 e Figura 2). Elas propõem uma nova forma de visualidade, já que a imagem produzida neste contexto é complexa por estar associada à dialética do espaço de produção como o que pretende representar e, portanto, a cidade, lugar de intercâmbio social, adquire sua identidade ao definir-se como uma espécie de individualidade conglomerada. 
Figuras 1- A ocupação de um não lugar pode ser percebida em Ver a cidade, grafite de Mauro Neri.

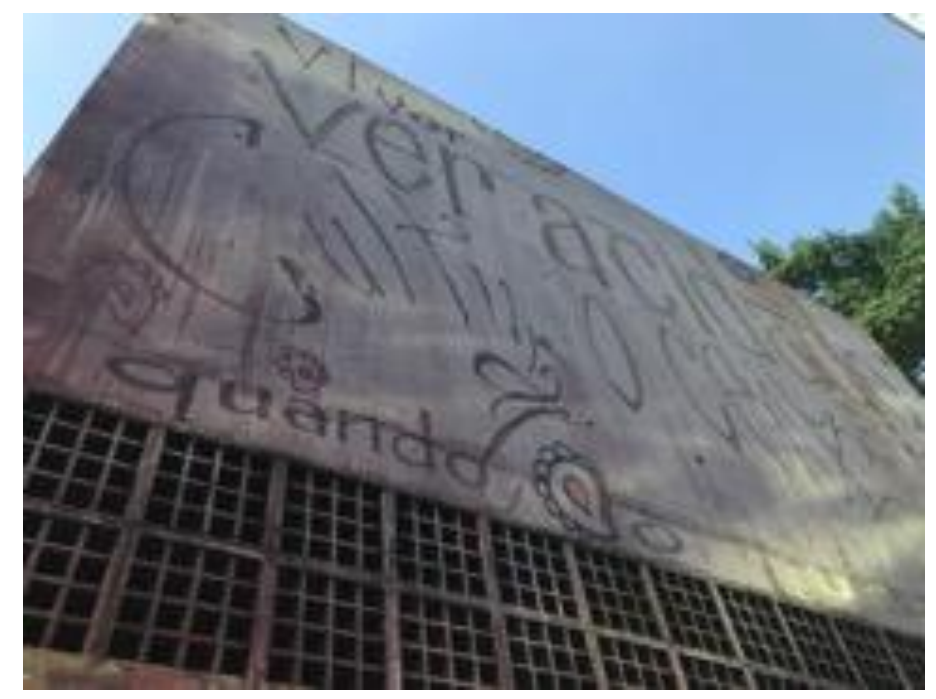

Fonte: Reprodução de fotografia realizada pelo autor na passagem na Avenida Vergueiro com Avenida 23 de Maio, em 2019.

Figura 2 - Obra na Avenida São João (aqui o observador precisa rodear a obra).

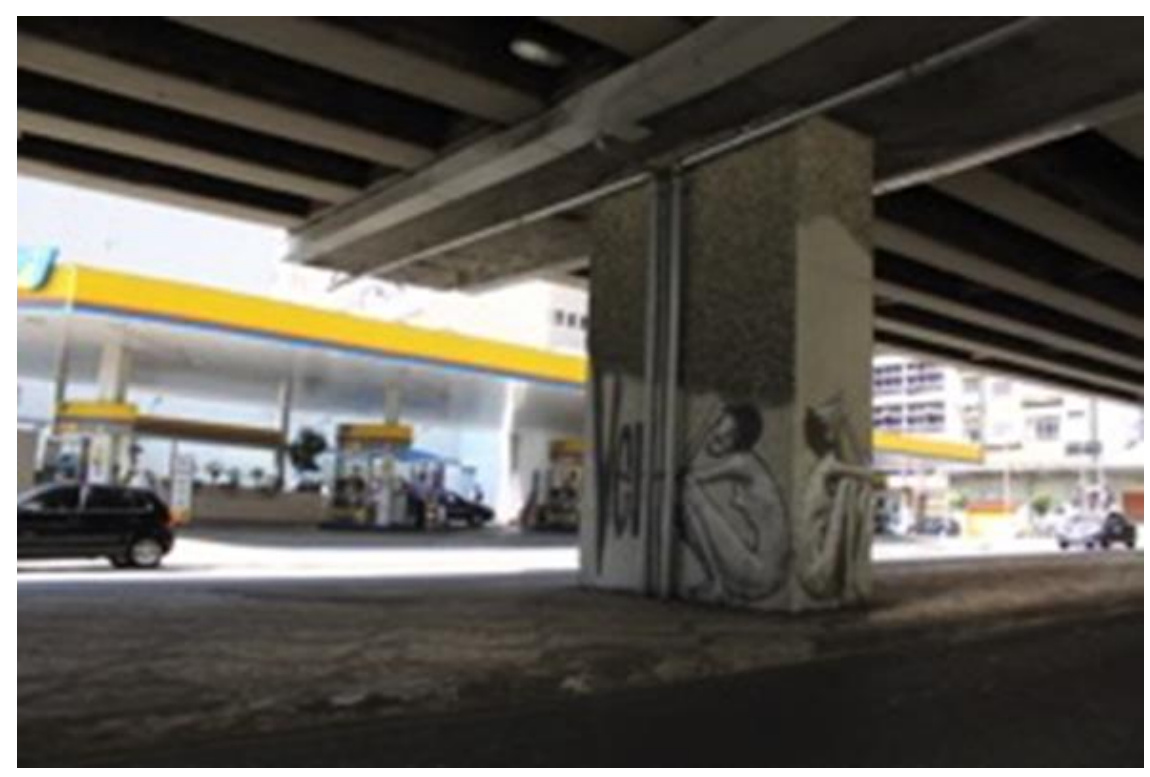

Fonte: Reprodução de fotografia realizada pelo autor, em 2019.

Da mesma forma que a grafitecidade, recorrendo a Maffesoli (1990), une elementos de várias identidades de tribos que se encontram em um terreno comum, sem fundir os diversos caracteres e vozes em uma identidade social exclusiva; assim, o que pode ser a raiz de um conflito, em realidade entrelaça e converte a maldição de babel em dádiva (Figura 3). 


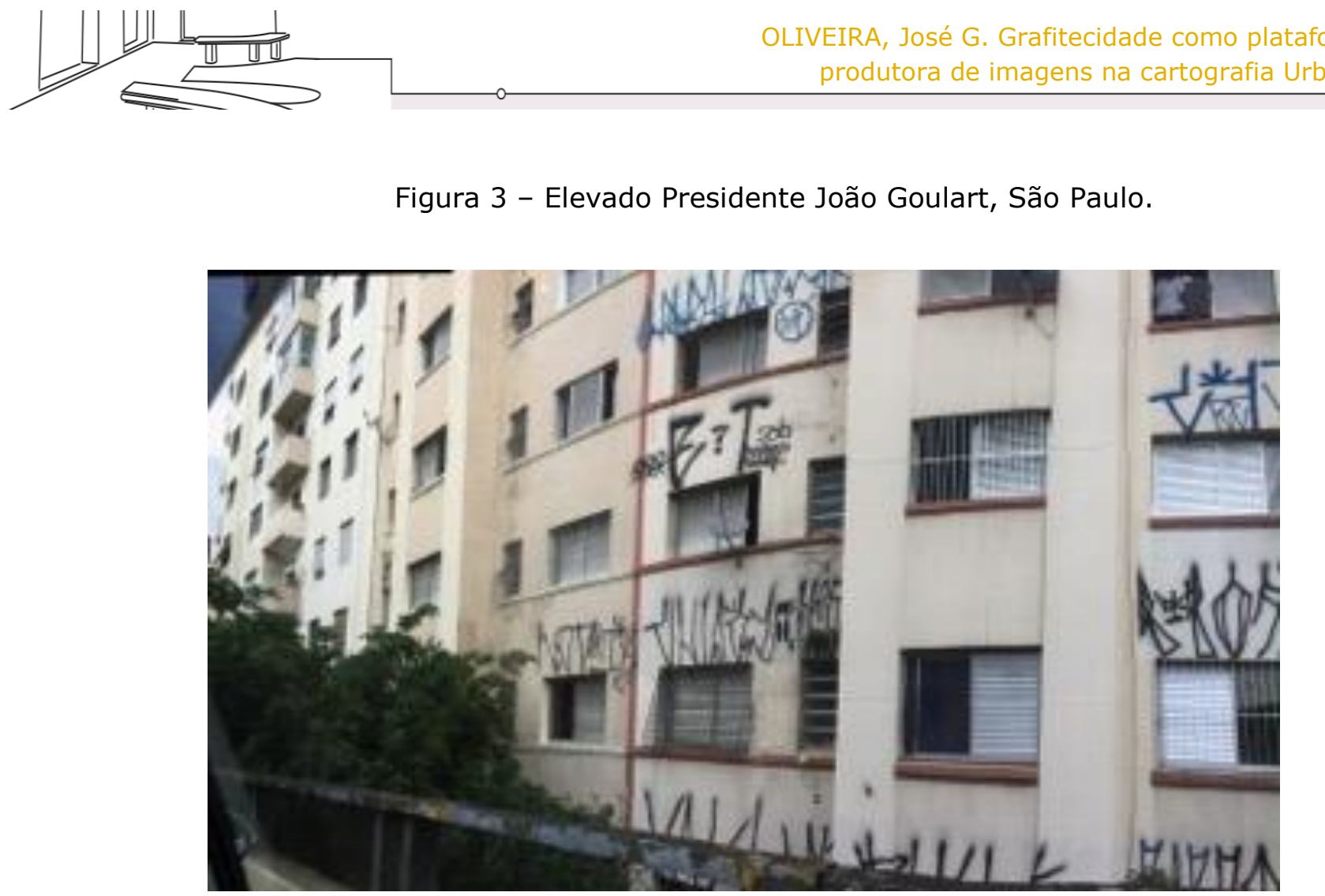

Fonte: Reprodução de fotografia elaborada pelo autor, em $2019^{3}$.

Composta por linhas ou rizomas ${ }^{4}$, sem centro ou periferia, a grafitecidade expõe uma necessidade da busca de identidade, a construção de uma narrativa, que tem o propósito de dar expressão e contexto às experiências privadas, de tal maneira que, reconhecidas pelo tecido social, as percepções/expressões individuais podem adquirir um sentido de pertencimento compartilhado na tensão entre ambas, que permite a coexistência e confere identidade.

As representações narrativas, nesta plataforma, que o caminhante transforma em outra coisa a cada significação espacial, devem ser tratadas sobre o critério da complexidade. Quando falamos de complexidade e cidade

3 Os artistas desenvolvem várias estratégias e táticas de visibilidade, conforme Certeau (1999) e isso é a chave para tratarmos das práticas de inscrições no espaço urbano.

4 É uma aproximação e aplicação dos princípios elaborados por Deleuze e Guattari (2004): os seis princípios da teoria do rizoma são: conexão, heterogeneidade, multiplicidade, ruptura cessionária, cartografia e cacofonia. A partir desta formulação é possível entender, entre muitos significados e interpretações possíveis, que em um sistema rizomático todos os pontos podem ser conectados a outros, independentemente da sua natureza, e este sistema pode ser quebrado em qualquer parte, e sofrer construções e mutações constantemente, ilustrando processos de territorialização, desterritorialização e reterritorialização.

REU, Sorocaba, SP, v. 45, n. 2, p. 331-357, dez. 2019. 
estamos nos referindo ao que é tecido em conjunto. Quer dizer, ao que está inter-relacionado e entranhado.

O critério de complexidade passa pela complexidade postulada por Morin (2005), mas principalmente pelas ideias de Català (1993, 2005) que é responsável por extensas pesquisas nas áreas da cultura visual e dos estudos da imagem onde aponta o surgimento de formas de representações hibridas e complexas. Ao mesmo tempo uma nova forma de interagir com as imagens que, dotadas de complexidade, podem cumprir uma função epistemológica e didática, sem abandonar sua subjetividade ou apelo estético.

Assim, a grafitecidade passa a ser apreendida pelo observador como uma forma de montagem cinematográfica, através da visão travelar ${ }^{5}$, uma forma de montagem subjetiva, uma relação que mantém com as tramas recolhidas, atribuída a partir de uma união de vários signos e símbolos que remetem à percepção de uma análise também fragmentada. Ou seja, segundo Bolle (1996), uma montagem como fragmentação e união de blocos de um material visual que modifica sua estrutura e configura a percepção do caminhante.

Uma paisagem com ritmo, enunciações surgidas na interação do observador em movimento, que produz uma conjunção de olhar nos interstícios urbanos já que o corpo do observador também se faz presente e o observador não é um mero receptor passivo, ele codifica e decodifica, devolvendo a sua (re)significação a esta cacofonia de elementos que constitui um "sistema ecológico de comunicação" (Figura 4). Elementos comunicacionais se entrelaçam e se convertem em um elemento estéticosensorial em que emerge a transitoriedade e a condição do efêmero.

Segundo Costa (2011), a ecologia da comunicação é uma ciência das relações e interações que existem entre as diferentes espécies de atividades

\footnotetext{
${ }^{5}$ Uma referência a travelling. É todo movimento de câmara em que esta realmente se desloca no espaço - em oposição aos movimentos de panorâmica, nos quais a câmara apenas gira sobre o seu próprio eixo, sem se deslocar.
}

REU, Sorocaba, SP, v. 45, n. 2, p. 331-357, dez. 2019. 
de comunicação dentro de um sistema social disperso em um território. Assim, é possível pensar os fenômenos comunicativos mais além da compreensão meramente instrumentalista e assumi-la como um ecossistema. Quer dizer, quando defendemos a ideia de um "sistema ecológico de comunicação" no contexto da grafitecidade, nos referimos a uma abordagem que integra, sobre a metáfora do ecossistema, os processos comunicativos, assim como as interrelações entre eles. Também consideramos que o modo em que são construídas, a partir de todo este conjunto de interações, "configurações" entre pessoas que se comunicam, incluindo a transgressão entre os dispositivos comunicacionais.

Figura 4 - Rua da Consolação, São Paulo.

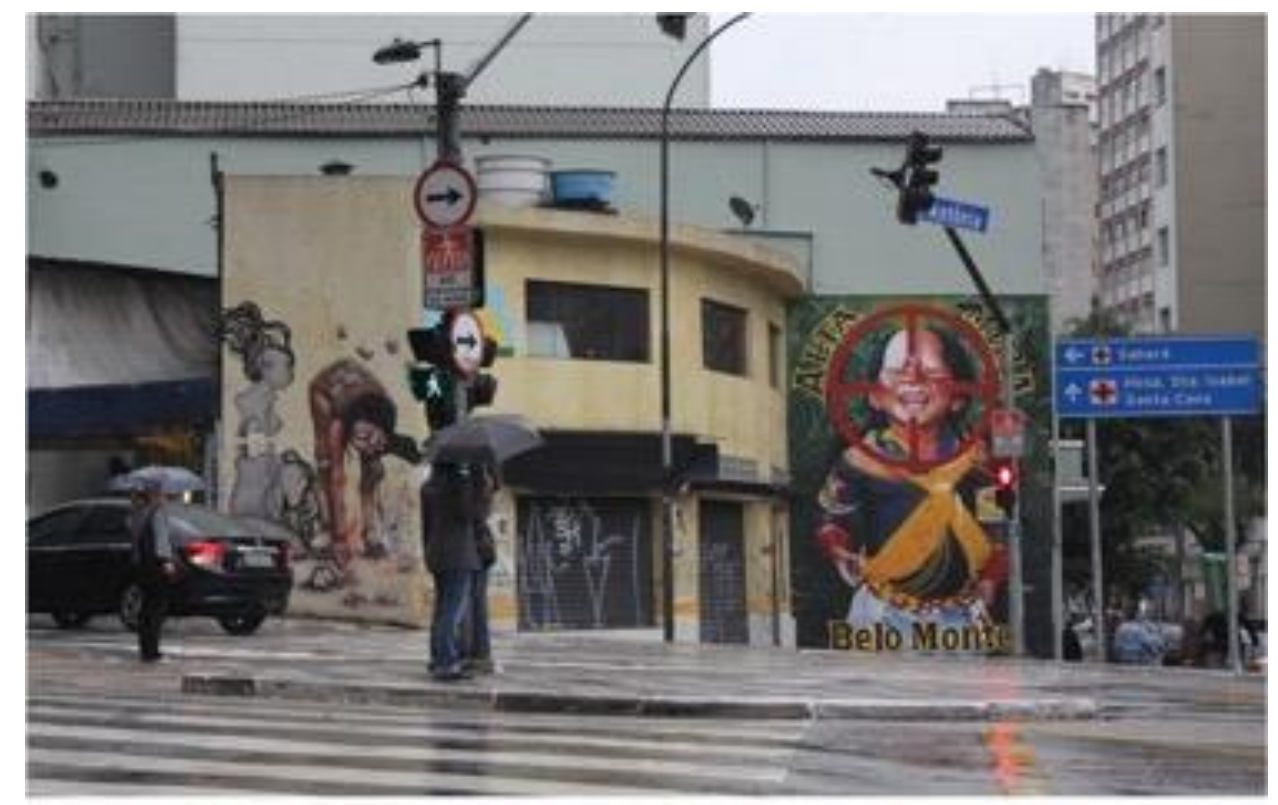

Fonte: Reprodução de fotografia realizada pelo autor, em $2019^{6}$.

Para entrar na complexidade da grafitecidade é necessário entender a noção de cartografia e percebê-la como um rizoma. O uso que Deleuze e Guattari (2004) fazem deste conceito é de um modelo descritivo ou epistemológico em que a organização de determinados elementos não segue

6 Observar a complexidade. Por sobreviver livremente na paisagem, as imagens são instáveis pela efemeridade. Tornando-se essencialmente complexas, pois estão associadas à própria dialética do espaço de produção como pelo que ela deseja representar. 
linhas de subordinação hierárquica. O conceito de rizoma descrito em Mil mesetas: capitalismo y esquizofrenia (2004) pode funcionar como um ponto para pensar a multiplicidade da grafitecidade, tanto espacial como nas produções que ocorrem no seu interior.

É possível pensar o concepto de rizoma como um tipo de linhas sem centro determinado, ligadas a pontos de uma forma binaria, subordinadas à verticalidade e à horizontalidade. Qualquer ponto de um rizoma, conforme Deleuze e Guattari (2004), pode ser ligado a outro, que rompe em qualquer lugar e retorna sua forma segundo uma de suas linhas ou segundo outras linhas. "Um rizoma não começa nem acaba, sempre está no meio, entre as coisas, inter-ser, intermezzo" (DELEUZE; GUATTARI, 2004, p. 29). E ainda, o rizoma se refere a um mapa.

O mapa é aberto, conectável em todas suas dimensões, desmontável, alterável, susceptível de receber constantes modificações. Pode ser rasgado, alterado, adaptado a distintas montagens, iniciado por um indivíduo, um grupo, uma formação social. Pode ser desenhado em uma parede, conceber como uma obra de arte, ser construído como ação política ou como uma meditação (DELEUZE; GUATTARI, 2004, p. 18).

Outro ponto importante é a ideia de que o mapa não reproduz um inconsciente fechado sobre si mesmo, ele o constrói e "contribui para a conexão dos campos, ao desbloqueio dos corpos sem órgãos, a sua máxima abertura em um plano de consistência" (DELEUZE; GUATTARI, 2004, p. 18). Outro aspecto que se destaca no rizoma é o fato de ter múltiplas "entradas" e comportar às vezes uma "nítida distinção entre linhas de fuga como corredores de deslocamento" (DELEUZE; GUATARRI, 2004, p. 18). O mapa é uma questão de performance.

Na cartografia da grafitecidade, a percepção não acontecerá em um ponto ou em ordens, serão só linhas e trajetos a serem construídos. Cada vez que há uma ruptura no rizoma, as linhas segmentárias explodem em uma linha de fuga que também é parte do rizoma: as linhas não param de remeter a outras em uma criação labiríntica que pode ser gerada espontaneamente. Quer dizer, a cartografia na grafitecidade se constrói a 
partir do descobrimento de um território a ser percorrido; portanto, estamos falando de um espaço narrativo visual e que a sua construção é uma performance particular, tanto do artista como do caminhante. Uma vez que o território é um ato,

[...] que afeta os meios e os ritmos, que os "territorializa". O território é o produto de uma territorialização dos meios e dos ritmos [...] A territorialização é o ato do ritmo tornado expressivo, ou dos componentes de meios tornados qualitativos (DELEUZE; GUATTARI, 2004, p. 321-322).

\section{As Visões da Cidade}

A cidade é um tema recorrente na obra de Walter Benjamin (2009). A metrópole é apresentada pelo pensador como morada e imagem mental do coletivo: território de múltiplos conflitos sociais e de transformações urbanísticas. Situada em uma época de grandes mudanças (o período entre guerras e as reformas urbanísticas promovidas pelo Barão Haussmann), Paris se converte em uma cidade habitada por homens que se perdem em labirintos e espaços sensoriais, multidão de imagens onde, para Benjamin, "nada é para o outro totalmente nítido nem totalmente opaco (BENJAMIN, 1989 , p. 46). As novas técnicas de reprodução, entre elas o cinema, surgiram a partir da segunda metade do século XIX. Nesta perspectiva, ele propõe pensar as mudanças que configuram a modernidade a partir das transformações do modo de percepção e recepção da experiência social da coletividade humana nos centros urbanos. O que Bolle (2000, p. 19) acredita: "A construção do olhar sobre a cidade acontece através das imagens dialéticas, fragmentos [...] e técnicas de montagem, configurando um ensaio 'cinematográfico', uma 'radiografia da metrópole'"'.

Diante deste caleidoscópio, se impõe ao observador uma ação que revela novas "constelações" de formas, e a percepção implica interpretar não somente signos explícitos, mas, segundo Benjamin (2009, p. 502), "os farrapos, os resíduos: não quero inventariá-los, e sim fazer-lhe justiça da única maneira possível: utilizando-os". 


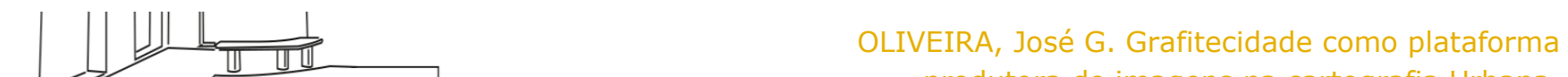

Sempre é uma tentação recorrer a ideia do flâneur para pensar na cidade e a arte transgressora. Na literatura de Charles Baudelaire esta figura está intimamente ligada a construção do moderno. Como uma entidade que caminha pela cidade, o flâneur elege um ponto de vista com a finalidade de apreendê-la. É tomado por ela, mas mantém distante ao sair. Uma posição de "viajante do imaginário" que está próximo e distante, e por isto tem a capacidade de perceber sua transitoriedade - o que Benjamin (2009, p. 465) definiu como "dialética da flânerie" - , penetrar na multidão com o objetivo de estar no outro e perceber a realidade, abandonando a ideia do pathos da distância e o modelo perspectivo renascentista.

Baudelaire descreve a cidade metaforicamente como a experiência embriagadora de tomar um "banho de multidão", o que acrescenta Benjamin (2009), no Livro das passagens, um observador com a paixão e a profissão de "desposar a multidão", um caminhante no "grande deserto dos homens". É inaugurado, assim, um culto ao frenesi urbano, uma apologia à multidão e a "embriaguez religiosa das grandes cidades" (BENJAMIN, 2009, p. 335).

É preciso tomar muito cuidado ao utilizar as ideias de Benjamin, ou aplicá-las para falar das cidades de hoje. O pensador é um ponto de partida. O autor refletiu e vivenciou a metrópole e criou uma representação da vida tumultuada considerando dois vigorosos conceitos de sua época: centro e periferia, algo que se dilui na grafitecidade, pois as fronteiras se rompem nas existências de vários centros e, consequentemente, em várias periferias que se renovam e modificam a geografia da circulação. Benjamin, até aqui chegamos. A partir daqui é preciso colocar as velas em movimento.

Como pensar esta experiência da modernidade no desenho comunicativo da grafitecidade? Neste espaço, como identificar elementos comunicativos, uma vez que tudo pode ser informação e nem tudo pode comunicar? No universo da grafitecidade, e apropriado do conceito de "rizoma", o artista transgressor é a "atualização" da figura do flâneur, atuando no espaço/tempo, deslocando na intenção da busca do pertencimento em uma nova modalidade: informação, comunicação e 
pertencimento. Isto acontece, acredito, porque o lugar é sempre e, ao mesmo tempo mutável e é, às vezes, o mesmo o mesmo lugar na memória, o mesmo de sempre, e ao mesmo tempo outro, "a memória deve a sua mesma capacidade de poder alterar-se: pode deslocar, é móvel e não tem lugar fixo" (CERTEAU, 2000, p. 96).

\section{A Cidade como Palimpsesto: imagem arquetípica para leitura do mundo}

O teórico de literatura Gérard Genette (1989) utiliza a figura do palimpsesto para elaborar uma teoria para análise de textos literários como portadores de outros textos neles escondidos. Este procedimento que Genette estabeleceu para o mundo textual pode ser transportado para outras instâncias, como por exemplo, elementos que lidam com a história, memória e no nosso caso a cidade.

O que importa aqui é o conceito de "revelar o que está escondido" na sobreposição de mensagens. Desta maneira, podemos relacionar a cidade como um grande palimpsesto e as inscrições urbanas com a escritura, que não sempre cobre o que anteriormente estava escrito no suporte arquitetônico em que está incrustrado, "verdadeiros enigmas as serem decifrados" (PESAVENTO, 2004, p. 26).

Enquanto a cidade, começamos pela materialidade, este espaço construído que se expõe de forma arquitetônica e no traçado urbano, perceptível ao olhar. Como diz o teórico francês, citando o escritor Thomas de Quincey: "O palimpsesto da memória é indestrutível, é sempre possível resgatar, pela invocação, experiência e sensações adormecidas" (GENETTE, 1989, p. 7).

A cidade contemporânea tem pelo menos três traços comuns: identificatória (pertencimento e identidade), relacional e histórica (memória); nela é possível encontrar palimpsestos de imagens que se oferecem como verdadeiros enigmas por ser decifrados, pois seus substratos funcionam como a acumulação de marcas de historicidades imagéticas sobrepostas no tempo e que se ampliam além dos traços 
materiais ou da escrita. A memória penetra entre essas imagens (Figura 5). Esta marca é possível recuperar como metáforas para abordar o passado de uma cidade. Uma espécie de arqueologia do olhar, para encontrar o oculto, que deixou pistas.

Estes acumulativos urbanos (visuais) estão situados além das marcas da historicidade temporal e ressoam passando aos rasgos materiais e alcançando o plano cultural. Quando consideramos a cidade como um sistema comunicativo aberto, por onde circulam corpos, este espaço cria paisagens que possibilitam visualizar o que pode existir embaixo, entre e sobre as capas dos palimpsestos espacial e temporal.

Figura 5 - Grafite e pichação

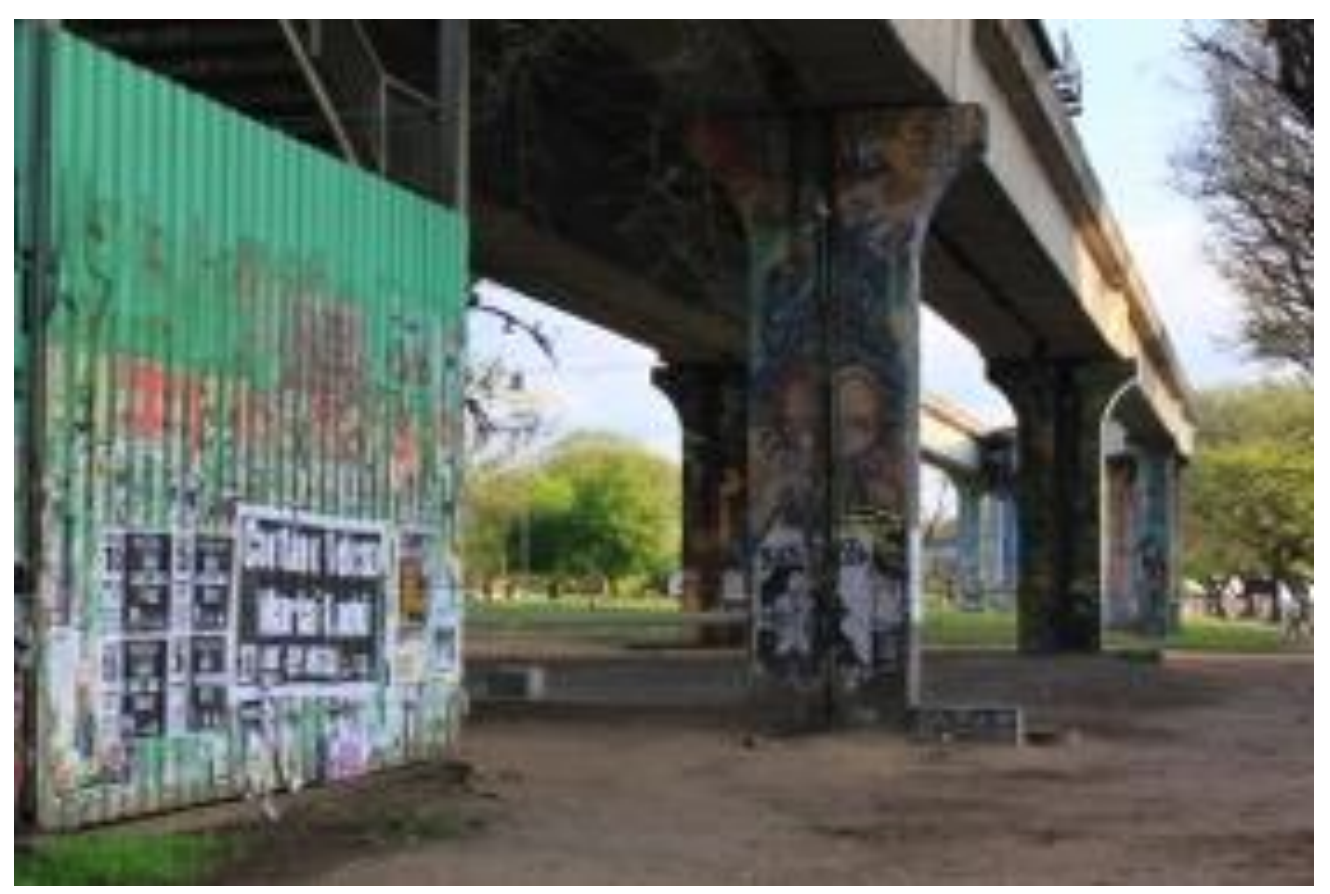

Fonte: Reprodução de fotografia realizada pelo autor, em $2019^{7}$.

A produção imagética na grafitecidade se configura como uma imagem complexa em que ocorrem tensões e é neste umbral que se efetua a

${ }^{7} \mathrm{Na}$ imagem é possível observar várias camadas históricas de imagens. O grafite e a pichação convivem outras formas de comunicação visual. Também é possível perceber a noção de palimpsestos e a efemeridade das imagens, imagens que se sobrepõem uma a outra deixando rastro de um passado imagético. 
comunicação e a geração de sentido. Estes códigos tramados abaixo, entre e sobre capas criam paisagem para nichos imagéticos que remetem a conexões para decodificar a metrópole. As imagens no espaço urbano, inclusive as raspadas e resenhadas, guardam a possibilidade de novas leituras para compreender a cultura e seus signos.

Em relação à cidade, é possível perceber que o olhar se prende aos detalhes de construção arquitetônicas, ora ordenadas, ora desordenadas. Podemos pensar que qualquer imagem neste espaço é apenas um ponto do passado, uma imagem de um cemitério de palimpsestos. Não existe "presente" na imagem da cidade. E assim como o pensamento, novas cartografias subjetivas são construídas a todo instante. A imagem da cidade só pode ser (re)construída pelo efeito da memória, que não segue uma ordem linear de agrupamento das lembranças. As imagens se montam e se fragmentam, e se reorganizam tornando-se palimpsestos, metáforas de conexões de imagens.

Em As siglas em cores no trabalho Passagens de W. Benjamin, Bolle (1996, p. 55) afirma que:

A existência de afinidades entre a topografia da grande cidade e as estruturas mentais de seus habitantes era uma concepção cara a Benjamim: "Desde há muitos anos, estou brincando com a ideia de organizar o espaço da vida (bios) graficamente, na forma de um mapa".

O pensador alemão imaginou um mapa de uma cidade que "é igual ao mapeamento de sua vida afetiva" ou "um mapa mnemônico estritamente pessoal de Berlim" (BOLLE, 1996, p. 55) ${ }^{8}$.

8 O arquiteto italiano Francesco Careri, em Walkscapes, o andar como prática estética, de 2014, nos guia por diferentes episódios históricos tomando como eixo o tema do andar como um ato cognitivo capaz de transformar o espaço e seu significado. Também em Lynch (1998) encontramos referências para entender como se conforma a imagem da cidade e proporciona uma análise que explora a percepção e a interação das pessoas com a forma e a geografia urbana.

REU, Sorocaba, SP, v. 45, n. 2, p. 331-357, dez. 2019. 


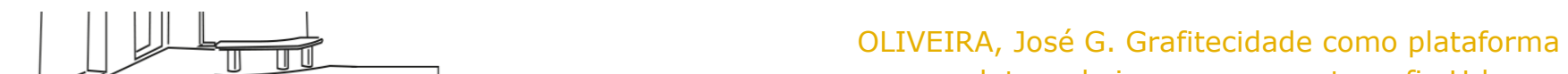

\section{A Cidade e os seus Interstícios Narrativos}

Henri Lefebvre em vários dos seus estudos defende que o espaço, por ser um produto social, supõe contradição da realidade e revela diferenças e particularidades contextuais. Construído assim, o espaço logo se torna "abstrato" com a força da razão estética e das imagens. A experiência imediata e sensível pode "reprimir a abstração ao retirar o estancamento e a homogeneidade artificial do conceito de espaço, escreve em A revolução urbana; ou seja, "o espaço urbano se converte em um enclave onde se opera o contato entre as coisas e as pessoas, onde tem lugar o intercâmbio" (LEFEBVRE, 1970, p. 8).

Em La producción del espacio (LEFEBVRE, 2013), o sociólogo aponta três instantes nesta produção social; a) o espaço "concebido", que é o da representação abstrata traduzida por um pensamento capitalista estático e distante do real; b) o "percebido", surgido das intermediações entre a ordem distante e próxima, com o desdobramento de práticas espaciais surgidas nos atos e relações especificas da formação social, e c) o "vivido", que denota as diferenças em relação com o modo de vida programado. Em uma curta análise, percebemos que não há uma imutabilidade entre as dimensões espaciais e, por isso, nada impede que o espaço "concebido" absorva o espaço das representações (o vivido).

Por sua vez, Certeau (2000) concebe o espaço associado a um lugar conduzido em um deslocamento, um "cruzamento de objetos moveis" ou um "lugar praticado". Ele destaca que sem a noção de mobilidade não seria possível haver espaço, porque só ficariam lugares fixos e imutáveis e nãolugares.

A cidade, como nome próprio, oferece a este modo a capacidade de conceber e construir o espaço a partir de um número infinito de propriedades estáveis, ilhadas e articuladas uma sobre as outras. (CERTEAU, 2000, p. 106).

Em El murmullo de las imágenes, Català (2012) retoma essa discussão sem tratar o não-lugar como local em que desaparece a cidade. Ele sugere que o não-lugar, espaço não comum por excelência, se transformou 
finalmente em "um lugar comum". Mas o êxito desta noção, continua, "obedece ao fato de que, na nossa sociedade, sumariamente codificada, onde todos os espaços públicos e privados estão sobre controle e somente permitem o uso institucional estabelecido, o não-lugar, a heterotopia, se converte em zona de mistério". E que, portanto, suscita todo tipo de atenção, "desde a curiosidade até rejeição, ao tempo que permite e impulsiona a reconfiguração das ações e dos discursos" (CATALÀ, 2012, p. 59).

A cidade tem muitos não-lugares, como os terrenos baldios, sem edificações ou espaços em que existiram edifícios que hoje desapareceram. A própria deterioração da cidade cria os não-lugares e, se queremos recorrer à conferência dos "Espaços outros", ditada por Foucault (1967), no Círculo de Estudos Arquitetônicos, os próprios hotéis e as zonas de ruas de passagens com funções concretas podem conter não-lugares.

Depois de entender as noções de espaço, lugar e não-lugar, pode-se pensar na grafitecidade que transforma a noção do não-lugar em espaços de práticas subversivas de pertencimento, por meio de narrativas visuais que têm o objetivo de narrar para "saber quem somos". Ou, nas palavras de Certeau (1999, p. 30): "uma linguagem, desde que se fala - a partir que é respirável - envolve sinais, fontes, uma história, uma iconografia, em suma, uma articulação de 'autoridade'". O próprio artista transgressor e rebelde se posiciona diante das metrópoles como a "existência" de uma voz que é imagética e que tem uma força emocional. Para Certeau (2000, p. 114), o caminhar "seleciona e fragmenta o espaço percorrido; salta os nexos e as partes inteiras que omite. A partir deste ponto de vista, todo andar segue saltando, ou jogando, como a criança que anda 'em um só pé'".

Esta é uma visão poética de Certeau, mas o que acontece quando o observador está em movimento (dentro de carros, trem, ônibus)? Como é esta percepção a partir do movimento? O observador em travelling se apropria de partes menores, com o propósito de compor um todo, uma operação potencializada pelo movimento e a fragmentação. 


\section{Visão Travelar e Montagem Subjetiva como Areensão da Grafitecidade}

A prática da montagem subjetiva implementa a poética da flânerie, perdida hoje, mas exaltada por Baudelaire, e que Benjamin considerava símbolo da modernidade: o isolamento na multidão, o anonimato e a experiência do choque. A cidade se transformou em uma paisagem sem limite que contém nela, e através dela, um laboratório de experimentações visuais. Se a pós-modernidade sepultou o flâneur e a flânerie, fez renascer também a figura dos artistas transgressores que se apropriam dos nãolugares e os transformam em espaços ritualistas de experiências revelando o axioma da mobilidade. Um estado de neo-flânerie que permite deslocarse na complexidade da grafitecidade e conviver com os meandros e entranhas do cotidiano ${ }^{9}$. A grafitecidade cria um processo relacional com os não-lugares com a intenção de apreender a cidade em todo o seu conjunto para, ao final, totalizar estes espaços urbanos, trazendo à tona sua singularidade, gerando a visão de um território que não quer ser anônimo ou transitório no nível da mobilidade.

A montagem no cinema é uma conjunção de mundo que cria um sentido. De maneira clássica, um filme é constituído de sequências, unidades menores dentro dela, marcadas por uma função dramática ou narrativa. As sequências, por sua vez, estão constituídas de cenas, dotadas de unidades espaço/temporais.

A montagem constrói cenas a partir dos pedaços separados [...] a sequência destes pedaços não deve ser aleatória, mas corresponde à transferência natural do observador imaginário (que, no final, está representado pelo observador) (PUDOVKIN, 1983, p. 60).

Na grafitecidade, este sentido é o da adição, a soma que cria um paralelismo visual em vez da continuidade. $O$ observador recolhe

\footnotetext{
9 Ver o ensaio visual São Paulo, a capital da pichação!, realizado pela Artepixo (2017). Estamos diante de um novo tipo de flâneur. O flâneur eletrônico que expande nossa visão travelar e expande o conceito a partir do uso de drones.
} 
fragmentos visuais e tenta criar sequências lógicas dando significados a uma narrativa subjetiva. Ele assume a câmera e o papel do montador, e o faz para narrar uma história ou reorganizar um roteiro visual ou simplesmente organizar a informação que the é oferecida de forma fragmentada. A percepção das imagens e das mensagens ocorre através de montagens depois do deslocamento do corpo do observador na geografia do percurso urbano. Isto instaura uma nova percepção do objeto, é isto que chamo visão em estado de travelling ou visão travelar. Esta visão totalitária só é possível através de uma foto panorâmica. A nossa visão de comporta também desta maneira. No movimento travelar o nosso olhar realiza uma montagem de imagens como um conjunto, sem de deter em uma específica. (Figura 6).

Figura 6 - Visão travelar. Mergulhão da Avenida Paulista.

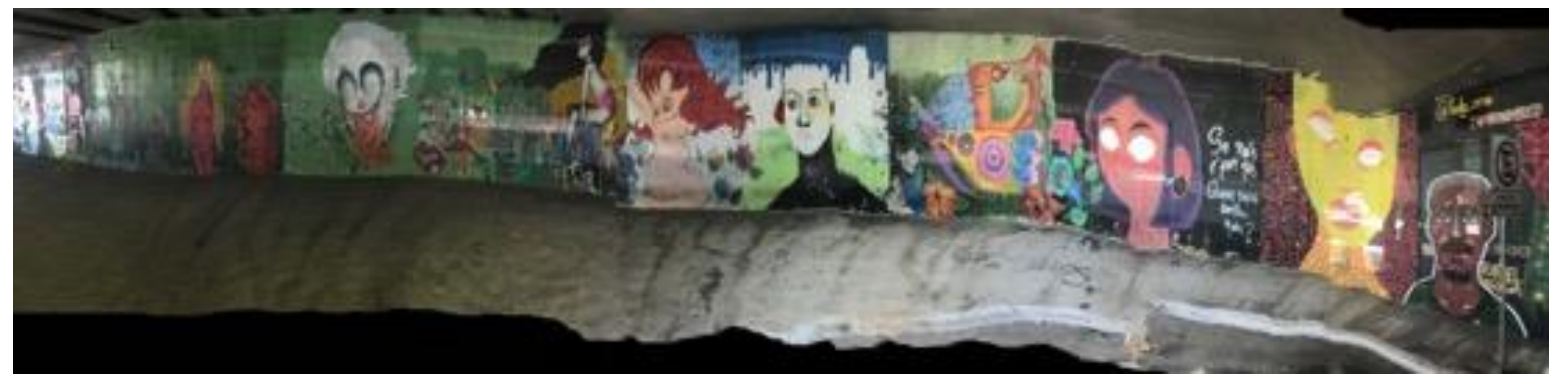

Fonte: Reprodução de fotografia realizada pelo autor, em 2019.

Manovich (2006) defende que, diferentemente das narrativas literárias ou teatrais e na pintura bastam apenas as técnicas colocadas em cena. No caso de uma escultura ou arquitetura, e neste ponto podemos inserir a arte urbana, "o espectador tem que mover todo seu corpo para experimentar a estrutura espacial" Manovich (2006, p. 104). Da mesma forma, nossa relação com a cidade e com os elementos visuais dessa paisagem exige circular, passear, para obter o efeito de um travelling. Assim, a percepção das imagens e suas mensagens estão "em estado de travelling"; quer dizer, o deslocamento se converte em uma experiência fundamental que permite escapar da ordenação espacial do olhar para entrar nos não-lugares, o que seguramente nos leva a uma "transterritorialização" geograficamente circunscrita. 
A convivência perceptiva e sensorial na grafitecidade vai além da concepção simplista de ocupação de um não-lugar. Por trás de gestos e vozes rebeldes, é possível perceber a intenção de uma construção simbólica que retira o caráter insólito do não-lugar e cria um imaginário urbano provocado por percepções da experiência do observador.

Vamos nos deter neste ponto. A visão travelar associada ao movimento passa a significar a presença na realidade urbana e, sobretudo, a ação sobre ela. Não falamos de uma cristalização simbólica imaginária, e sim da capacidade de interferir na percepção que temos do não-lugar e em sua transformação.

O caráter singular de produção de sentido acontece quando consideramos a grafitecidade como um campo visual informacional por constituir um espaço de circulação de informações (Figura 7).

Figura 7 - Ação da visão travelar, de Carlos Adão.

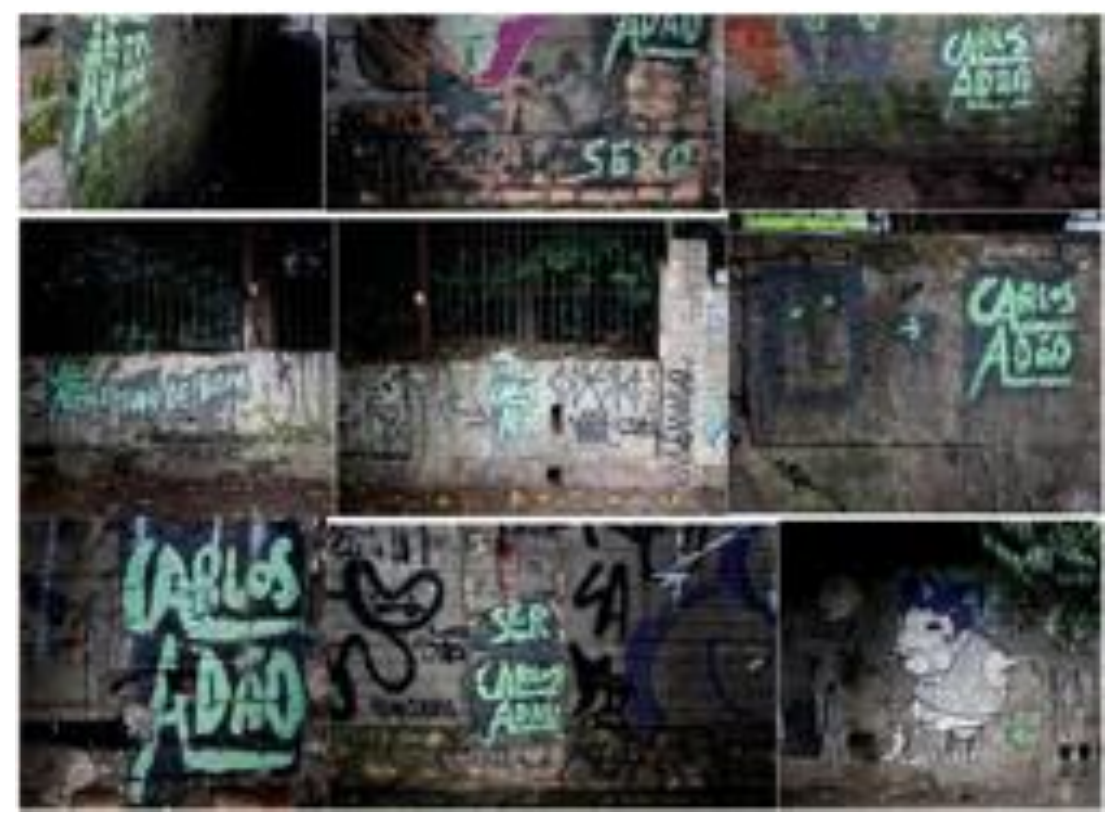

Fonte: Reprodução de fotografia realizada pelo autor, em 2019.

A percepção, segundo Ferrara (1999, p. 153), "é informação na mesma medida em que a informação gera informação". A investigadora defende que o espaço e a informação são elementos interdependentes, já que não é possível conceber, apreender um espaço senão através do seu uso e hábitos derivados do modo de produção que os caracterizam, da 
mesma maneira que os usos e hábitos constituem a manifestação concreta do lugar urbano, na mesma medida em que o lugar é manifestação concreta do espaço.

Não é absurdo afirmar que a nossa visão ficou condicionada à visualidade cinematográfica. Conceptualmente consideramos que o observador, na montagem subjetiva, reorganiza temporal, espacial e mentalmente as imagens, transformando-as em reflexões visuais, pois elas estão abertas as sobreposições e combinações arbitrarias que materializam a imagem de uma nova "arquitetura do imaginário". A ação da visão travelar está nas inscrições de Carlos Adão, em que o artista cria uma sequência de inscrição em uma mesma rua, que quando o observador está em movimento tem a sensação de estar diante de uma sequência cinematográfica que conta uma história.

\section{Estruturas Imaginárias da Imagem na Grafitecidade: montagem subjetiva e a reapropriação do não-lugar}

O sentido da visão, segundo Català (2011), nos oferece experiências que parecem tão imediatas que temos a sensação de ser capaz de compreender rapidamente. Há uma série de padrões preconcebidos que "delimita, filtra e adjetiva o que vemos", o que configura a maneira de "representar o que vemos", estruturando o nosso imaginário em diferentes camadas acumulativas.

O imaginário pessoal, relativo à nossa cultura visual particular; são aquelas imagens que conhecemos e que nos afetam pessoalmente. [...] O imaginário social, corresponde à visualidade relativa à sociedade em que estamos imersos. Existem diferentes graus, que podem ir desde o entorno social imediato [...] a uma classe social. [...] O imaginário cultural refere à visualidade cultural [...] onde cada sociedade dita o que se pode ver, mas também como se pode ver. 0 imaginário antropológico se relaciona à visualidade com as estruturas profundas que dão lugar à formação das imagens (CATALÀ, 2011, p. 252-253, grifo do autor).

Como já vimos anteriormente, as imagens incrustadas na cidade são dialéticas por natureza e destituídas de marcos, tempo e estão sobre a regia do efêmero. São compostas de "resíduos e vestígios" da vida cotidiana, que 
o colecionador benjaminiano transforma em algo passível de construção de uma história-memória. Assim, a atuação deste colecionador também se torna dialética, pois considera a relação com o passado (um não-lugar) em uma intenção de despertar algo que está ali em estado latente, de sonho, à espera de uma reapropriação.

A grafitecidade se converte em uma heterotopia, um conceito da geografia humana elaborado por Foucault que descreve lugares e espaços humanos que funcionam em condições não hegemônicas, ou seja, com múltiplas capas de significações ou de relações com outros lugares, cuja complexidade não pode ser vista imediatamente. Para Català (2012), estes espaços heterotópicos estão situados ou imersos nas representações. Uns são espaços transitáveis, são cenários para a imaginação; outros são espaços dentro da estrutura da representação, que são "buracos efetuados no espaço diegéticos que conectam com a realidade, mas, através deste movimento, permitem que o real seja invadido também pelo imaginário (CATALÀ, 2012, p. 70).

Se já introduzimos Walter Benjamin nesta discussão, é possível ainda abordar outro pensador alemão, Aby Warburg (2010), pois as imagens na grafitecidade também estão imantadas de história, de uma existência de gestos que provocam a memória, ou a uma "imagem sobrevivente" surgidas das narrativas de narrativas apropriadas da mobilidade e do deslocamento na geografia urbana.

A ênfases no aspecto da memória e do visual é o eixo central de uma "ciência sem nome" especulada por Warburg (2010), que esboçou uma teoria geral da memória social baseada em imagens e fortemente firmada nas relações complexas entre o visual e o significado, que necessariamente implica ações ritualísticas e imagens mentais. Um ponto importante é a relação entre imagem e narrativa, aqui considerada como a "montagem subjetiva" que surge da percepção imagética e sua emergência e sobrevivência com pegadas mnemônicas (Figura 8). 


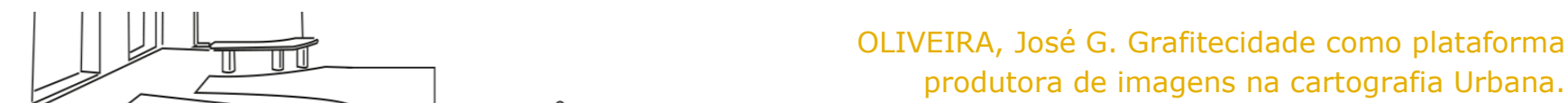

Figura 8 - Montagem da evolução do grafite usando como modelo Atlas Mnemosyne.

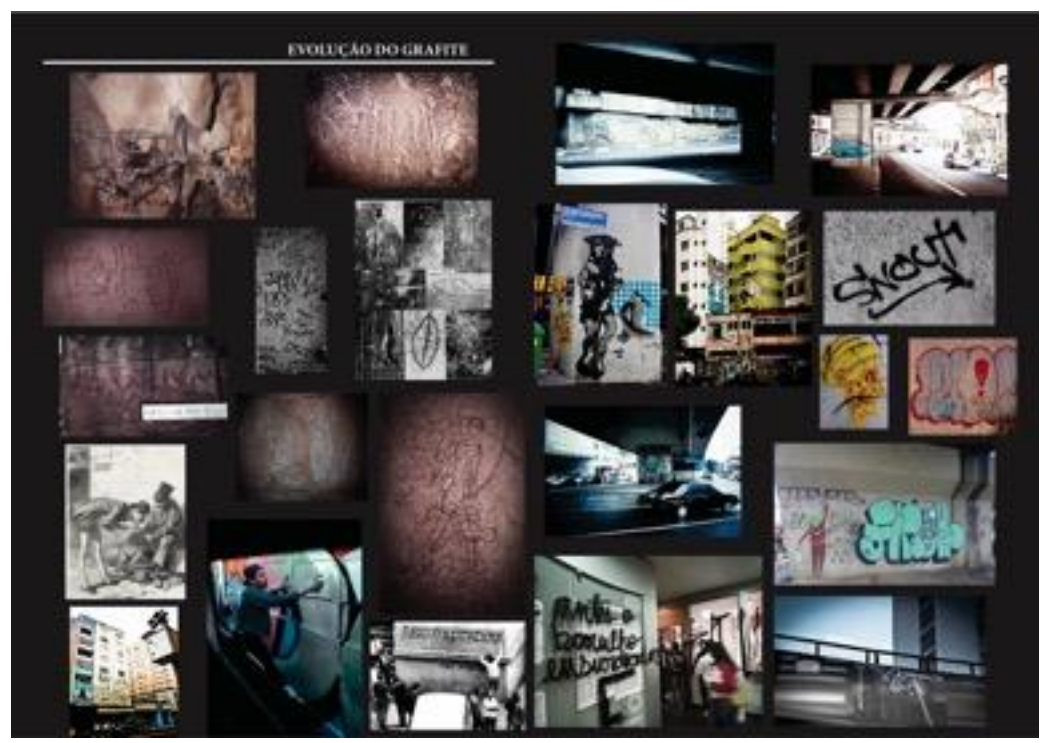

Fonte: Montagem elaborada pelo autor, em 2014.

Para o transeunte, a paisagem da grafitecidade pode parecer fragmentos de várias cidades contidas nela. Destes ambientes, sobre a égide do tempo, ritmo, espaço e memória flutuam um fluxo narrativo, em que as mudanças de velocidade, a desaceleração, a aceleração, as paradas, os desvios, as bifurcações criam novas montagens subjetivas em um "processo de apropriação do sistema topológico por parte do caminhante" (CERTEAU, 2000, p. 110). Isto acontece por meio do encontro perturbador entre o indivíduo e o espaço, entre a imagem privada e a pública, entre o visível e o não visível. Nestes momentos despontam os vários laços entre as distintas narrativas e a construção de imaginários e memórias sociais

A montagem subjetiva evoca a supervivência das imagens em um ritual de construção da história no gesto simples dos rebeldes visuais. Mas este processo é eficaz, pois pretende marcar na memória um momento particular e efêmero do tempo, como um anagrama, ou seja, a imagem gravada que nos transmite reflexos futuros, fazendo das intervenções um ato político estético.

As inscrições urbanas devem ser tratadas como traços mnemônicos e não só como representações urbanas, na medida em que compartem a mesma complexidade (a conjunção de traços contraditórios) que define a

REU, Sorocaba, SP, v. 45, n. 2, p. 331-357, dez. 2019. 
qualquer imagem, carregada de realidades, referida a verdadeira natureza pictórica. O conceito de Pathosformel, elaborado por Warburg (2010), é um modo de explicar a transmissão de uma memória coletiva por meio das imagens, e o conceito de sobrevivência traduz a possibilidade de transmissão. A sobrevivência não é um caminho de continuidade do tempo cronológico, mas de transmissão de conteúdo com valores expressivos que não se extinguem por Pathosformel.

As imagens na grafitecidade são produzidas sempre em um contexto ritualista, na perspectiva warburguiana da transgressão e da subversão: os grafites são impensáveis sem a rebeldia, sem a ocupação não autorizada do espaço público.

O grafite, com sua linguagem artística, opera mais facilmente no nível mnemônico e evoca uma contemporaneidade marcada pela transgressão da cultura contemporânea. Mas vale observar que

Diante de uma imagem - tão recente, tão contemporânea, que seja o passado não cessa nunca de reconfigurar-se, uma vez que esta imagem só pode ser pensada em uma construção da memória, quando não uma obsessão" (DIDI-HUBERMAN, 2008, p. 32).

Isto aponta uma ferramenta para um futuro estudo da grafitecidade e suas possibilidades, em que as imagens, dotadas de una vida póstuma, nos fazem recordar a ideia de palimpsestos, de atravessar alguns períodos encobertos e regressar constantemente, para possibilitar assim sua análise. E isto sucederia não de forma linear, em que "um depois" seria a consequência de "um antes" e estaria influenciado por ele, mas ao contrário: é um diálogo constante entre o passado e o presente, sem a preocupação de registro do tempo ou localização espacial, pois, na grafitecidade, o caminhante dialoga com imagens de tempos diferentes e as atualiza segundo suas eleições. 


\section{Considerações Finais}

A grafitecidade é uma plataforma instável e que tem a capacidade de partir até outra direção, por conter um estado de mobilidade complexa dependente da propensão ao movimento e da circulação urbana em que as identidades, tanto coletivas como individuais, não se manifestam mais. Mas é possível afirmar que os artistas transgressores buscam criar uma paisagem de diálogos por meio de uma busca comunicacional hibrida, confluência de tensões e marca de pertencimento e territorialidade.

$\mathrm{Na}$ grafitecidade, ao realizar uma montagem de tempos, temos a oportunidade de avaliar como se planteiam as questões do presente para o passado e, de posse das respostas obtidas, questionar o tempo atual. Com isto, a arte transgressora passa a desempenhar o papel de um espaço de enunciação do próprio comportamento do homem omitido na sociedade.

Nas ruas, os artistas tecem a geografia da cidade. Para os transgressores, a cidade é um espaço de realização e um campo de investigação e de comunicação que apresenta novas possibilidades de ver e de sentir. Estas intervenções passam a constituir vozes que revelam pontos de conflitos existentes em várias esferas, no campo político, ideológico, ético, poético, ou simplesmente na própria existência contemporânea que define as narrativas gráficas das mensagens. A expressão dos artistas da transgressão trata do ínfimo, e eles encontram na cidade um espaço para comunicar os devaneios, manifestação das inquietudes e anseios diante de uma metrópole que propõe um falso igualitarismo e homogeneização, que leva a uma perda de sentido de pertencimento. E eles, por meio de suas transgressões gráficas, criam novas formas de se relacionar com o espaço.

Alguns destes trabalhos se diluem na dinâmica da cidade, ao mesmo tempo em que se aproveitam as possibilidades de fruição que o ambiente urbano propicia, pois a cidade se move em um ritmo que se sobrepõe à obra de arte. Os cartazes ou inscrições são recolados um sobre outros em muito pouco tempo, e inclusive as intervenções dos artistas convivem com as sobreposições palimpsestas, inclusive ações de política pública, que cobrem 


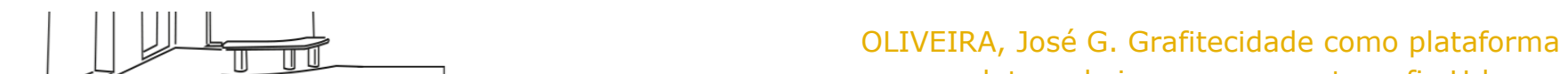

ou apagam os registros. Há uma consciência de que suas obras são efêmeras e por isto relegadas ao esquecimento ${ }^{10}$.

\section{Referências}

ARTEPIXO. São Paulo, a capital da pichação! 2017. In: BENJAMIN, Walter. Obras escolhidas III: Charles Baudelaire, um lírico no auge do capitalismo. São Paulo: Brasiliense, 1989.

BENJAMIN, Walter. Obras escolhidas III: Charles Baudelaire, um lírico no auge do capitalismo. São Paulo: Brasiliense, 1989.

BENJAMIN, Walter. Passagens. Belo Horizonte; São Paulo: Imprensa Oficial do Estado de São Paulo; Editora UFMG, 2009.

BOLLE, Willi. A fisiognomia da metrópole moderna: representação da história em Walter Benjamin. São Paulo: Edusp, 2000.

BOLLE, Willi. As siglas em cores no Trabalho das Passagens, de W. Benjamin.

Estudos Avançados, São Paulo, v. 10, n. 27, p. 41-77, 1996. Disponível em: http://www.scielo.br/scielo.php?script=sci_arttext\&pid=S010340141996000200003 . Acesso em: 19 out. 2019.

BRASSAÏ. Brassaï grafites. Madrid: Círculo de Bellas Artes, 2008.

CATALÀ, Josep M. La violación de la mirada. Madrid: FUNDESCO, 1993.

CATALÀ. Josep M. La imagen complexa: La fenomenológia de las imagenes en la era de la cultura visual. Bellaterra: Servei de Publicacions, 2005.

CATALÀ, Josep M. A forma do real: introdução aos estudos visuais. São Paulo: Summus, 2011.

CATALÀ, Josep M. El murmullo de las imágenes: imaginación, documental y silencio. Cantabria: Shangrila, 2012.

CERTEAU, Michel de. La cultura en plural. Buenos Aires: Ediciones Nuevas Visiones, 1999.

CERTEAU, Michel de. La invención de lo cotidiano I: arte de hacer. México: Instituto Tecnológico y de Estudios Superiores Del Occidente, 2000.

COSTA, Juan. Ecología de la comunicación e interacción social. Pensar la Publicidad. Revista Internacional de Investigaciones Publicitarias, Madrid, v. 4, n. 2, p. 17-24, 2011. Disponível em:

http://revistas.ucm.es/index.php/PEPU/article/view/PEPU1010220017A/15014. Acesso em: 18 out. 2019.

DELEUZE, Gilles; GUATTARI, Felix. Mil mesetas: capitalismo y esquizofrenia. Valencia: Pre-textos, 2004.

DIDI-HUBERMAN, George. Ante el tiempo: historia del arte y anacronismo de las imágenes. Buenos Aires: Adriana Hidalgo, 2008.

DIDI-HUBERMAN, George. O que nós vemos, o que nos olha. São Paulo: Editora 34, 1998.

${ }^{10}$ Ver o caso do projeto Cidade Linda, do prefeito João Doria, em São Paulo, que apagou diversos grafites da cidade.

REU, Sorocaba, SP, v. 45, n. 2, p. 331-357, dez. 2019. 
FERRARA, Lucrécia. O olhar periférico. São Paulo: Edusp, 1999.

FOUCAULT, Michel. De los espacios otros. 1967. Disponível em: http://escolanomade.org/wp-content/downloads/foucault-de-outros-espacos.pdf. Acesso em: 23 out. 2019.

FOUCAULT, Michel. El cuerpo utópico: las heterotopías. Buenos Aires: Nueva Visión, 2010.

GENETTE, Gérard. Palimpsestos: la literatura en segundo grado. Madrid:

Taurus, 1989.

JOLY, Martine. La imagen fija. Buenos Aires: La Marca, 2012.

LEFEBVRE, Henri. La producción del espacio. Madrid: Capitán Swing Libros, 2013.

LEFEBVRE, Henri. La revolución urbana. Madrid: Alianza Editorial, 1970.

LYNCH, Kevin. La imagen de la ciudad. Barcelona: Gustavo Gili, 1998.

MAFFESOLI, Michel. El tiempo de las tribus: el declive del individualismo en las sociedades de masas. Barcelona: Icaria, 1990.

MANGUEL, Alberto. A cidade das palavras: história que contamos para saber quem somos. São Paulo: Cia. das Letras, 2008.

MANOVICH, Lev. EI lenguaje de los nuevos medios de comunicación: la imagen en la era digital. Buenos Aires: Paidós, 2006.

MORIN, Edgar. Introdução ao pensamento complexo. Porto Alegre: Sulina, 2005.

OLIVEIRA, José G. Grafitecidade e visão travelar: comunicação visual, rebeldia e transgressão. Saarbrücken: Novas Edições Acadêmicas, 2014.

PESAVENTO, Sandra Jatahy. Com os olhos no passado: a cidade como palimpsesto. Revista Esboços, São Carlos, v. 11, n. 11, p. 25-30, 2004. Disponível em: https://periodicos.ufsc.br/index.php/esbocos/article/view/334 Acesso em: 11 set. 2019.

PUDOVKIN, Vsevolod. Métodos de tratamento do material (montagem estrutural). Os métodos do cinema. O diretor e o roteiro. In: XAVIER, Ismail (org.). A experiência do cinema: antologia. Rio de Janeiro: Graal, 1983. p. 57-73.

REGUILLO-CRUZ, Rossana. En la calle otra vez: las bandas. Identidad urbana y usos de la comunicación. Tlaquepaque, Jalisco: ITESO, 1991.

REGUILLO-CRUZ, Rossana. Pensar la ciudad desde la comunicación. In: GALINDO, J.; LUNA, C. [org.]. Campo académico de la comunicación: hacia una reconstrucción reflexiva. México: ITESO-Conaculta, 1995. p. 109-132.

REGUILLO-CRUZ, Rossana. Identidades culturales y espacio público: un mapa de los silencios. Diálogos de la Comunicación, v. 59, n. 60, p. 75-86, 2000. Disponível em: http://dialogosfelafacs.net/wp-content/uploads/2012/01/59-60revista- dialogos-identidades-cultural.pdf. Acesso em: 21 set. 2019.

WARBURG, Aby. Atlas mnemosyne. Madrid: Akal, 2010. 